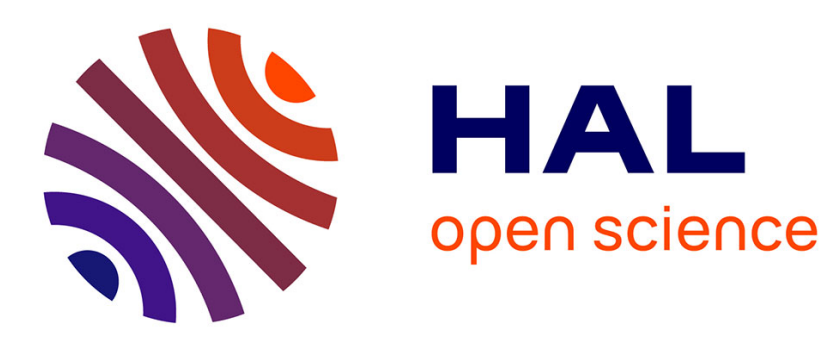

\title{
Water Flows in Rockwall Permafrost: a Numerical Approach Coupling Hydrological and Thermal Processes
}

\author{
Florence Magnin, J.-y Josnin
}

\section{To cite this version:}

Florence Magnin, J.-y Josnin. Water Flows in Rockwall Permafrost: a Numerical Approach Coupling Hydrological and Thermal Processes. 2020. hal-03024087

\section{HAL Id: hal-03024087 \\ https://hal.science/hal-03024087}

Preprint submitted on 25 Nov 2020

HAL is a multi-disciplinary open access archive for the deposit and dissemination of scientific research documents, whether they are published or not. The documents may come from teaching and research institutions in France or abroad, or from public or private research centers.
L'archive ouverte pluridisciplinaire HAL, est destinée au dépôt et à la diffusion de documents scientifiques de niveau recherche, publiés ou non, émanant des établissements d'enseignement et de recherche français ou étrangers, des laboratoires publics ou privés. 
1 Water Flows in Rockwall Permafrost: a Numerical Approach Coupling Hydrological 2

3 F. Magnin ${ }^{1}$ and J.-Y. Josnin ${ }^{1}$

$4{ }^{1}$ Université Grenoble-Alpes, Université Savoie Mont Blanc, Laboratoire EDYTEM, UMR5204, 573376 , Le Bourget du Lac, France

6 Corresponding author: Florence Magnin (florence.magnin@ univ-smb.fr)

7 Key Points:

- Coupling thermal and hydrological processes is necessary to better understand rockwall permafrost dynamics and geomorphic processes

- Water flows into bedrock fractures substantially affect permafrost aggradation and degradation patterns

- Water accumulation into ice-cemented bedrock may cause significant hydrostatic pressures favoring rockwall destabilization 


\section{Abstract}

Rockwall permafrost is extremely sensitive to climate change and its degradation is supposedly responsible for the recent increase in periglacial rock slope failures. Investigations of rockwall permafrost dynamics and mechanics have so far neglected possible hydrogeological processes acting in bedrock fractures. In this study, we propose the first numerical approach to couple thermal and hydrological processes in alpine rockwall permafrost and show that the latter have major effects on permafrost (thermal) dynamics and mechanics when the fractures and/or rock matrix are saturated. Water flows into fractures favor deep-reaching of the permafrost body by driving cold water top-down. Ice-filled fractures delay permafrost thawing in a first stage due to latent heat consumption but then accelerate it when the ice starts to melt. Thus, frozen fractures may subsist in thawed bedrock while thawing corridors may form in frozen bedrock. As a result, tmperature gradients are exacerbated. When connected fractures thaw, bottom-up permafrost degradation can occur through upwards propagation of thawing wedges delineated by these fractures. High hydraulic head values are associated to perched water table over or within the impermeable permafrost body, and correspond to hydrostatic pressures that can reach critical valus in trms of rockwall stability. These results bear strong implications to understand permafrost response to climate signals, periglacial geomorphology and hazards assessment as well as alpine hydrothermal processes.

\section{Plain Language Summary}

Permafrost (i.e. ground that remains at or below $0^{\circ} \mathrm{C}$ for at least 2 consecutive years) affecting the steep rock slopes in alpine or polar environments is extremely reactive to climate change. Its degradation (i.e. warming and thawing) is supposedly responsible for the increase in rock falls frequency and magnitude recently observed. Research conducted during the past decade have improved understanding of rockwall permafrost response to climate change and its role in rockwall destabilizations. However, the role of water flows into bedrock fractures that may result of rainfall, snow or glacier melt, has been overlooked because of the lack of understanding of these processes and the difficulty to study them. Based the recent developments in numerical tools, we here propose the first study that model water flows into rockwall permafrost to assess their role on permafrost distribution and evolution as well as in destabilization. The results show that permafrost distribution and evolution is more complex than originally thought when water flows were ignored. Permafrost can form well deeper due to cold water infiltrating from the mountain top, down in the rock mass. The ice contained in bedrock fractures may significantly delay permafrost thawing in th on hand, but can also provoke thawing acceleration when its start to melt in the other hand by forming thawing corridors and wedges along and between fractures. Water columns developing over or within the frozen rock mass may provoke high hydrostatic pressures that could favor bedrock destabilization. This study invites to rethink current knowledge on rockwall permafrost reaction to climate change, rockwall permafrost destabilization processes and alpine hydrogeology. 


\section{Introduction}

Rockwall permafrost has been investigated since the early 2000s in conjunction with the observed increase in periglacial rockwall failures (e.g. Allen et al., 2009; Gruber et al., 2004). So far, researches have been mostly driven by the hypothesis that permafrost degradation, i.e. deepening of the active layer (seasonal thaw) or warming of the permafrost body, provokes bedrock destabilization by altering ice-joints in bedrock fractures (Gruber \& Haeberli, 2007; Krautblatter et al., 2013). Laboratory experiments have largely supported this hypothesis. Davies et al. (2001) have for example shown that the factor of safety of an ice-joint decreases with increasing temperature from -5 to $-0.5^{\circ} \mathrm{C}$ where it reaches its minimal value. More detailed quantification of the temperature dependency of ice-joint strength was recently done by Mamot et al. (2018), while a comprehensive model of bedrock destabilization in relation with permafrost dynamics was proposed by Krautblatter et al. (2013).

In parallel, thermal modeling has shown the enhanced sensitivity of alpine rockwall permafrost to air temperature signal (Magnin et al., 2017; Myhra et al., 2017; J. Noetzli \& Gruber, 2009; Jeannette Noetzli et al., 2007). Permafrost models were used to assess thermal conditions at location of periglacial rockwall failures, confirming that many rockfall events occurred in warm permafrost conditions (i.e. permafrost $>-2^{\circ} \mathrm{C}$; Deline et al., 2013; Frauenfelder et al., 2018; Ravanel et al., 2017). Transient temperature models generally account for heat conduction processes in a saturated, homogeneous and isotropic rock media. But rockwall permafrost models also showed that rockfalls may occur in cold permafrost areas and prior to the maximum active layer depth (Gruber et al., 2004; Luethi et al., 2015; Ravanel et al., 2017). Assuming that such rockfalls likely result of ice-joint warming and thawing, this implies that non-conductive heat transfers may play a key role in permafrost degradation such as found for more porous terrains constituted of non-consolidated material and allowing significant water infiltration (Luethi et al., 2017; Scherler et al., 2010). This latter hypothesis is supported by the investigation from Hasler et al. (2011a) on water percolation along an experimental ice-filled cleft cementing two bedrock compartments. This study showed accelerated permafrost degradation and cleft-ice erosion due to advective heat transport by water flows. But such findings are difficult to verify through field observations. Direct temperature measurements into boreholes by Phillips et al. (2016) recorded short and intermittent temperature increase after snow melt, hinting at water percolation down to the thermistor chain. Geophysical soundings from Krautblatter \& Hauck (2007) and Keuschnig et al. (2017) have suggested deep-reaching cleft-water systems in rockwall permafrost during the thawing season. Observations of rockfall scars with ice-coat and water flow marks are also frequently reported (Fischer et al., 2010; Frauenfelder et al., 2018; Geertsema et al., 2006; Ravanel et al., 2017; Walter et al., 2020) and strengthen the idea that water circulation may play a key role in the triggering of periglacial rockwall failure; either by cleft ice erosion and a resulting loss of bonding at the rock-ice interface or through hydrostatic pressures.

Coupling thermal, hydrological and mechanical processes is a major research perspectives pointed out by Krautblatter et al. (2012) to go over current knowledge limits. Hydrological processes remain the least understood because they are non-linear and are difficult to observe. However, in the recent years, a wealth of numerical codes have been developed to fully couple thermal and hydraulic processes (Grenier et al., 2018). They have been so far mostly designed and used for high-latitude flat regions (e.g. Bense et al., 2012; McKenzie \& Voss, 2013; 
Rowland et al., 2011) but they offer new opportunities to explore and conduct systematic investigations on the role of hydrological processes in rockwall permafrost as well.

In this study, we claim that rockwall permafrost dynamics should be understood as a hydrogeological problem and we thus propose to rethink former thermal modeling approach by adopting a hydrogeological conceptualization to allow water input and flow at a scale of a mountain flank.

We aim at (i) proposing an appropriate numerical procedure to fully couple thermal and hydrological processes in alpine rockwall permafrost, (ii) testing the sensitivity of rockwall permafrost to fluid flows, and (iii) pointing out possible research directions hinted at by these new developments.

We first describe our conceptual and numerical approach to couple thermal and hydrological processes in saturated and unsaturated conditions. We then run four simulations with various saturation levels and water input into a fractured bedrock medium. Our simulations show the major importance of fluid flows into bedrock thermal dynamics and fluid pressure distribution, under saturated conditions. We finally highlight that developing such models is a key to improve understanding of rockwall permafrost (thermal) dynamics, alpine hydrogeology and morphodynamics (mechanics).

\section{Hydrothermal simulations}

\subsection{Preliminary concerns}

Magnin et al. (2017) have shown that 2D thermal models running over pluri-decadal time scale and forced with local air temperature measurements are able to reproduce measured borehole temperature in alpine rock wall at a depth of $>8-10 \mathrm{~m}$. Such models follow the approach designed by Noetzli et al. (2007) which consider typical alpine topography and the related topoclimatic control (sharp variation in elevation and sun-exposure resulting in important air temperature lapse rate and highly variable incoming short-wave solar radiation). They consider a saturated and homogeneous rock media with relatively high porosity compared to most rock types in order to indirectly account for fractures. In these approaches, water flows are neglected. However, water flows into frozen bedrock have been investigated for several decades in the frame of frost weathering studies. These investigations mostly focus on water migration through the pore space as a result of temperature change and freezing (see Matsuoka \& Murton (2008) for a review). Such processes are essential to understand bedrock fracturing and the preparation to rock slope failures. However, to address the triggering of rockwall failures, macroscale processes acting at the already existing failure plan are more relevant.

Recently, the study of Hasler et al. (2011a) have set up a conceptual model describing water circulation patterns in fractures of frozen rockwalls to question their thermal effect. This conceptual model first pointed out that non frozen fractures are preferential flow paths as moisture migration through bedrock pores has a minor role in the thermal regime of low-porosity rock. Then, it stated that high hydraulic gradients related to slope angle and high permeability due to macroscopic clefts results in unsaturated conditions and that bedrock permeability depends on the cleft ice content.

Because cleft saturation results of complex processes involving repeated freeze and thaw as well as discharge and loading cycles, the level of saturation of rockwall permafrost is a poorly known 
parameter. In this respect, we propose to steadily upgrade existing thermal models by first integrating macro and micro-scale water flows in a "traditional" approach assuming a fully saturated porous and fractured bedrock medium. Then, we initiate a step towards the consideration of unsaturated conditions by setting up an unsaturated model domain and running simulations with limited or enhanced water flows. To do so, we adopt a hydrogeological conceptualization by setting up a water table in an initially unfrozen mountain flank.

\subsection{Mathematical approach}

The equation for transient flow through an anisotropic 3D porous medium is obtained by plugging the Darcy law into the continuity equation as follow:

$$
\frac{\partial}{\partial x}\left(K_{S x x} \frac{\partial h}{\partial x}\right)+\frac{\partial}{\partial y}\left(K_{S y y} \frac{\partial h}{\partial y}\right)+\frac{\partial}{\partial z}\left(K_{S z z} \frac{\partial h}{\partial z}\right)=S \frac{\partial h}{\partial t} .
$$

with $K_{S}$ the hydraulic conductivity at saturation, $h$ the hydraulic head, $S$ the specific storage, $t$ the time and $x / y / z$ the three axes of space.

Into unsaturated media, the pressure head $\psi$ is negative and $h=z+\psi$ is lower than the same hydraulic head at the same altitude under saturated conditions. The first equation for unsaturated media thus becomes:

$$
\frac{\partial}{\partial x}\left(K_{\psi x x} \frac{\partial \psi}{\partial x}\right)+\frac{\partial}{\partial y}\left(K_{\psi y y} \frac{\partial \psi}{\partial y}\right)+\frac{\partial}{\partial z}\left(K_{\psi z z}\left(\frac{\partial \psi}{\partial z}+1\right)\right)=C(\psi) \frac{\partial \psi}{\partial t}
$$

with $C(\psi)=\frac{d \theta}{d \psi}, \theta$ being the moisture content. This second equation reduced to $1 \mathrm{D}$ vertical flow is known as Richard's equation properly: $\left(K_{\psi Z Z}\left(\frac{\partial \psi}{\partial z}+1\right)\right)=C(\psi) \frac{\partial \psi}{\partial t}$.

$\mathrm{K}_{\psi}$ designs the hydraulic conductivity for a given $\psi$. The values of $K_{\psi}$ are obtained through the classical van Genuchten - Mualem relationship :

$$
s_{e}=\left\{\begin{array}{c}
\frac{1}{\left[1+(A|\psi|)^{n}\right]^{m}} \text { for } \psi<0 \\
1 \text { for } \psi \geq 0
\end{array}\right\}, K_{R}=s_{e^{\frac{1}{2}}}\left\{1-\left(1-s_{\left.e^{\frac{1}{m}}\right)^{m}}\right\}^{2},\right.
$$

with the effective saturation se given by $s_{e}=\frac{\theta-\theta_{r}}{\theta_{s}-\theta_{r}}$, where $\theta$ corresponds to a given $\psi, \theta_{s}$ is the moisture content at saturation, $\theta_{r}$ is the residual moisture content, $\mathrm{K}_{\mathrm{R}}$ the relative hydraulic conductivity (relative to $\mathrm{K}_{\mathrm{S}}$ ), and $A, m$ and $n$ are van Genuchten parameters. For this study, we kept the van Genuchten - Mualem relationship, but other relationships could be used (Haverkamp, Brooks \& Corey, etc.).

The flow velocities obtained from the previous calculations are integrated into the advective dispersive-diffusive heat transport equation which is usually expressed as follows:

$$
\frac{\partial\left[\left(\varphi \rho_{C}\right)_{L}+(1-\varphi)\left(\rho_{C}\right)_{S}\right] T}{\partial t}=-\nabla \cdot\left[\left(\rho_{C}\right)_{L} q T-\Lambda \nabla T\right]
$$

with $\varphi$ the porosity (a-dimensional), $\rho_{C L}$ and $\rho_{C S}$ the volumetric heat capacities $\left(\mathrm{J} \cdot \mathrm{m}^{-3} \cdot \mathrm{K}^{-1}\right)$ of the liquid and solid phases respectively, $\Lambda$ the hydrodynamic thermal dispersion tensor, $\left(\mathrm{J}^{\mathrm{m}} \mathrm{m}^{-1} \cdot \mathrm{s}^{-1} \cdot \mathrm{K}^{-}\right.$ 
${ }^{1}$ ) that includes thermal conductivity, $T$ the temperature $(\mathrm{K})$ and $q$ the apparent flow velocity from Darcy or Richards equation $\left(\mathrm{m} . \mathrm{s}^{-1}\right)$. Then, the ice phase is included in the solid phase to modify only one parameter of thermal conductivity (and not the one related to fluids). The solid thermal conductivity $\lambda\left(\mathrm{W} . \mathrm{m}^{-1} \cdot \mathrm{K}^{-1}\right)$ remains:

$\lambda_{s}=\lambda_{s, 0}+\frac{\varepsilon_{i}\left(\lambda_{i}-\lambda_{s}\right)}{1-\varepsilon}$

with $\varepsilon_{i}$ the bulk fraction of the ice and $\varepsilon$ the bulk fraction occupied both by water and air. In the solid, the thermo-dispersion tensor is linked to the thermal conductivity through the solid bulk volume fraction, and is sufficient here, the fluid convection being beyond the scope of this study. Into the fractures, we used the Hagen-Poiseuille flow formulation that characterize laminar flow that is accounted for as follow (modified from Diersch 2004):

$Q=-\frac{a^{3}}{12 \mu}\left\|\overrightarrow{\operatorname{grad}} P-\rho_{w} \vec{g}\right\|$

where $Q$ is the water discharge, $a$ the aperture of the fracture in $\mathrm{m}, \mu$ is the dynamic viscosity, $P$ the water pressure, $\rho_{w}$ the density of water and $g$ the gravity's acceleration.

Concerning the addition of the ice in the whole medium, it is expressed throughout the bulk volume as: $\varepsilon_{a}+\varepsilon_{w}+\varepsilon_{i}+\varepsilon_{r}=1$, with $\varepsilon_{a}$ the bulk fraction of air, $\varepsilon_{w}$ the bulk fraction of water, $\varepsilon_{i}$ the bulk fraction of ice and $\varepsilon_{r}$ the bulk fraction of rock. A relation is established between ice and liquid. This relation, called the freezing function (Clausnitzer \&Mirnyy, 2015) links the mass fraction per bulk volume of the unfrozen liquid to the total liquid mass:

$$
F=\frac{\varepsilon_{w} \rho_{w}}{\varepsilon_{w} \rho_{w}+\varepsilon_{i} \rho_{i}}
$$

\section{(3)}

where $\rho$ is the density of the corresponding phase (i for ice and ${ }_{w}$ for water). This function $\mathrm{F}$ decreases with the fraction of ice. With a freezing point $T_{0}$, the ice forms gradually within a predefined temperature interval $\left[T_{0}-\frac{\Delta T}{2}, T_{0}+\frac{\Delta T}{2}\right]$ of the length $\Delta T$.

\subsection{Numerical approach}

We implement the hydrothermal model described above with Feflow ${ }^{\circledR} 7.0$ and 7.2 (DHIWASY GmbH), a finite elements numerical code for simulation of saturated or unsaturated flow coupled with mass and/or heat transport. In the recent years, the Pi-Freeze plug-in was added to take into account freezing and thawing processes. The use of Feflow and Pi-Freeze for hydrothermal modeling applied to permafrost cases has been successfully benchmarked in a model intercomparison study (Grenier et al., 2018).

\subsubsection{Study site and model domain}

\subsubsection{Study site settings}

In our study, we take the Aiguille du Midi (Mont Blanc massif, northwestern European Alps) as a study case. The Aiguille du Midi is a set of three granitic pillars culminating at 3842 $\mathrm{m}$ a.s.l. on the western margin of the Mont Blanc massif in France (northwestern European Alps; Fig. 1a-b). Its South pillar stands above the Glacier du Géant by about $200 \mathrm{~m}$ while its North Pillar dominates Chamonix, extending over a height of about $1400 \mathrm{~m}$ down to the Pèlerins 
glacier (Fig. 1c). The site is accessible by a cable car and host about half a million tourists every year (Fig. 1d). It is the starting point of the Vallée Blanche, a very popular ski route and one of the normal route to the Mont Blanc summit (4809 m a.s.1.). The Aiguille du Midi bedrock is structured by various fracture sets with predominance of N050 and N150 (Fig. 1d).

Thermal modeling with Feflow and Pi-Freeze was already applied on the top part of this site and evaluated against borehole temperature measurements by Magnin et al. (2017) considering saturated and homogeneous conditions with no water flow. We here extend the model domain to ensure coherence with hydrogeological concerns and design four study cases to test rockwall permafrost sensitivity to water flow.
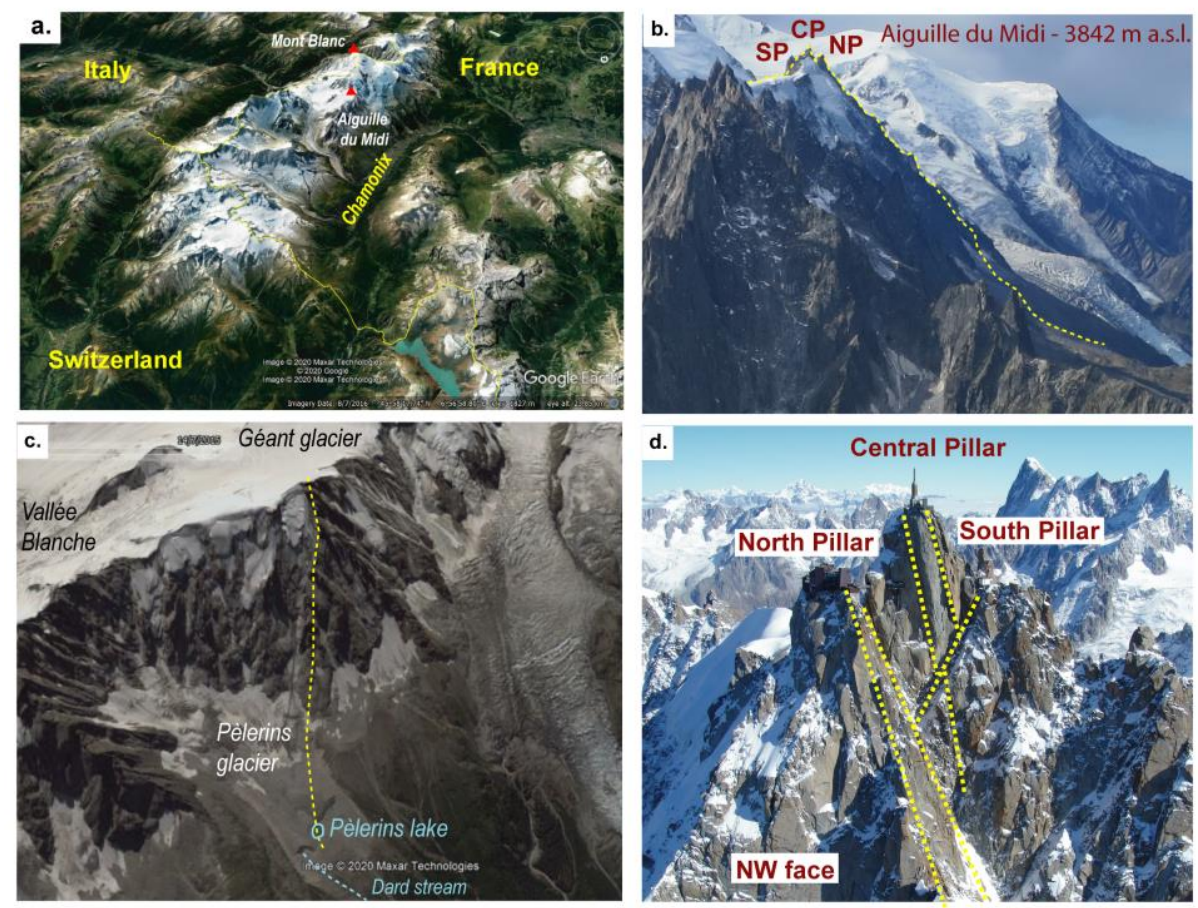

Figure 1. Study site and main features for determining model domain. a. The Mont Blanc massif. b. The Aiguille du Midi with the topographical profile considered in this study. SP: South Pillar, CP: Central Pillar, NP: North Pillar. c. The topographical profile considered in this study and main water outlet. d. Pictures of the Aiguille du Midi site with some of the main fractures identified to draw the model geometry (Pic: S. Gruber).

\subsubsection{General features of the model domain}

The topographical profile was extracted from a 4-m-resolution DEM provided by the regional authority (Régie de Gestion de Donnée Haute Savoie) to draw a 2D model domain. It extends from the bottom of the Central Pillar, at the edge of the Géant glacier, over the Central and North Pillars down to the foot of the glacier des Pèlerins where a lake forms intermittently (Fig. 1c). The profile was closed at its bottom and discretized into a network of 140,509 triangular elements and 70,879 nodes (Fig. 2). The mesh was refined around fractures because the high hydraulic gradient in between the fractures and the rock matrix could challenge the calculation.

Fractures were drawn to determine preferential flow paths by selecting a couple of the main fracture sets of the Aiguille du Midi based on various photos and field observations (Fig. 1d). 
Hydraulic conductivity is mostly influenced by fracture connectivity, density and aperture (Maréchal et al., 2004; Zhao, 1998, Long and Witherspoon 1985, Snow 1979). In a permafrost context, the hydraulic conductivity is furthermore dependent on the temperature as it is related to the unfrozen water content (Burt \& Williams, 1976). Interaction of the fracture characteristics and high temperature variability in alpine rockwalls is supposedly responsible for high and complex hydraulic gradients, which are also induced by the large elevation difference between the summit and the outlet. However, as a preliminary investigation, our study aims at ensuring results transparency and readability in order to facilitate interpretation of water flow effects in permafrost dynamics. We thus ignored fracture density and aperture and designed bedrock fractures with a concern of (i) connectivity, (ii) representativeness of the thermally-induced hydraulic gradient, and (iii) simplicity.

We selected a couple of the main fracture sets easily perceptible (Fig. 1d) and crossing both the rather colder north-exposed areas and warmer south-exposed areas (Fig. 2). Fracture aperture was set to $5 \mathrm{~cm}$ for long ones that represent faults and supposedly have an effect on water flow at the mountain flank scale and $2.5 \mathrm{~cm}$ for short ones that rather have an effect at the outcrop scale. We assumed constant aperture through depth. Thus, compared to real-world cases, we consider a realistic but largely simplified model geometry.

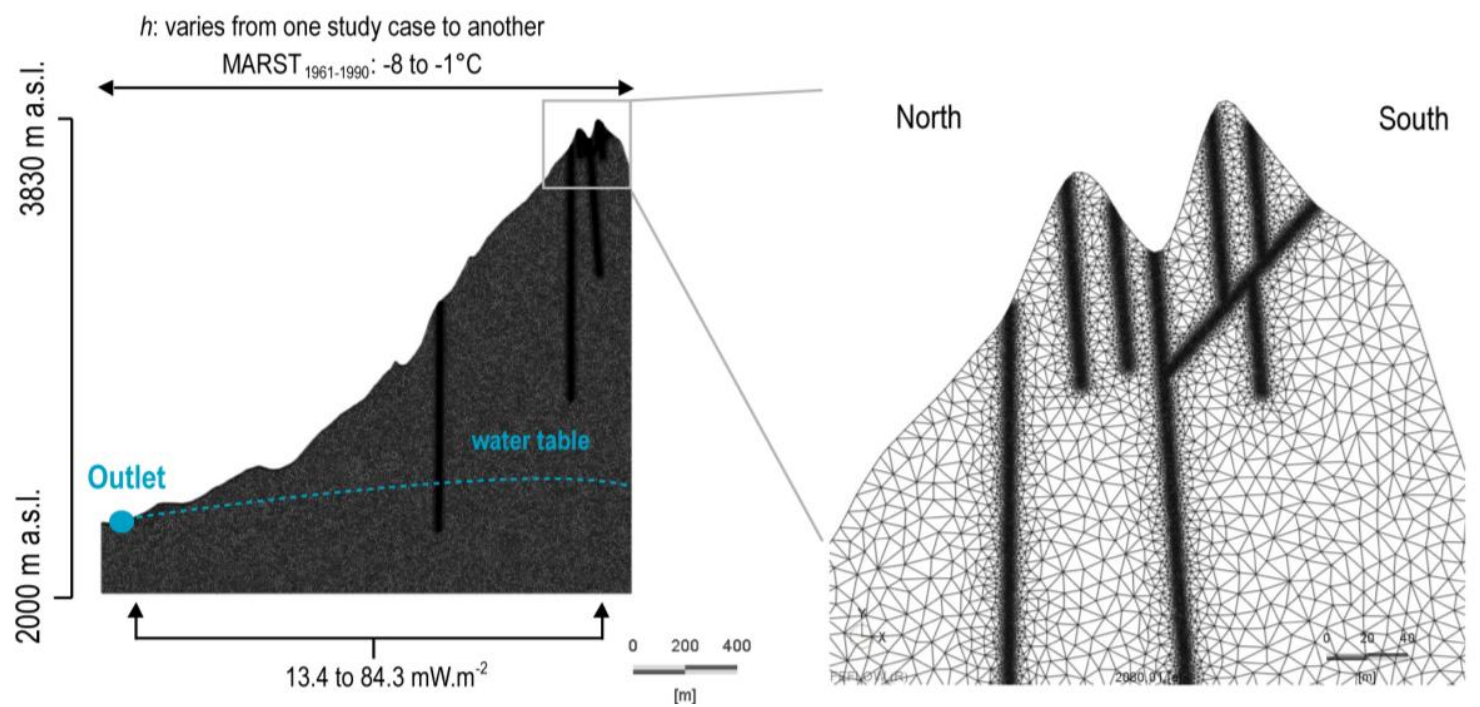

Figure 2: Model domain and initial conditions. The MARST was extracted from Magnin et al. (2015) and is representative of the 1961-1990 period. $h$ is the hydraulic head. The water table was set after a host of trial and error run.

\subsubsection{Model parameters and consistent boundary conditions}

In thermal modeling, main boundary conditions are the initial surface temperature and geothermal heat flux. Following previous thermal modeling approach of Magnin et al. (2017), the initial rock surface temperature was extracted from the temperature map of Magnin et al. (2015) implemented on the same $4 \mathrm{~m}$ resolution DEM as the one used for the topographical profile. The map represents the Mean Annual Rock Surface Temperature (MARST) calculated after the statistical model calibrated by Boeckli et al. (2012) which explains the MARST according to the 
mean air temperature of the period 1961-1990 and the potential incoming solar radiation. The initial MARST ranged from $-8^{\circ} \mathrm{C}$ to $-1{ }^{\circ} \mathrm{C}$ according to elevation and sun-exposure (see Fig. S1).

At the lower boundary, a geothermal heat flux was applied. We used the heat flux value calculated in the study of Magnin et al. (2017) at an elevation of $2000 \mathrm{~m}$ a.s.1 when applying $85 \mathrm{~mW} . \mathrm{m}^{-2}$ at 5 $\mathrm{km}$ below the Aiguille du Midi summit.

The thermal conductivity of the rock was set to $3 \mathrm{~W} \cdot \mathrm{m}^{-1} \cdot \mathrm{K}^{-1}$ which stands for a conservative value for saturated granitic rock (Cho et al., 2009) and the heat capacity of the rock mass was set to 1.8 $\mathrm{MJ} . \mathrm{m}^{3} \cdot \mathrm{K}^{-1}$. A bedrock porosity of $5 \%$ was assumed for the intact rock mass which accounted for a greater fracture density than the considered one. For the water, the thermal conductivity was set to $0.65 \mathrm{~W} \cdot \mathrm{m}^{-1} . \mathrm{K}^{-1}$ and the heat capacity was set to $4.2 \mathrm{MJ} \cdot \mathrm{m}^{3}$. $\mathrm{K}^{-1}$. Freezing was setup to occur at $-1^{\circ} \mathrm{C}$, the latent heat of fusion was $334 \mathrm{~kJ} \cdot \mathrm{kg}^{-1}$.

\subsubsection{Study cases with variable saturation and fluid flows}

We then test four study cases with contrasted hydrological setup (Tab. 1) so that a large panel of behaviors can be analyzed.

\subsubsection{Two cases in saturated conditions}

Case $\mathrm{Sa}-\mathrm{NF}$ is a "traditional" modeling approach with saturated conditions and no fluid flow (only conductive heat transport, similar to Magnin et al. (2017)). A hydraulic head of 3830 $\mathrm{m}$ a.s.l. is applied at all surface nodes (Tab. 1), which corresponds to the highest elevation point in the profile, and thus provokes saturated conditions and the absence of fluid flows.

$\mathrm{Sa}-\mathrm{Fl}$ was also saturated but accounted for fluid flow (allowing forced convection) by setting up a hydraulic head equal to the surface elevation for all surface nodes and was forced to remain constant. Water flows are provoked by the hydraulic processes related to topographical and thermal-related hydraulic gradient, and are further enhanced by a constant recharge and discharge at the rock surface to maintain a constant head. No outlet was specifically designed but was accounted for by the software itself.

\subsubsection{Two cases in unsaturated conditions}

We then run simulations in an unsaturated bedrock medium by setting up a water table with an initialization run (sect. 2.3.4). Little is known about water table levels in alpine environments (Cochand et al., 2019). Tunneling work and boreholes in crystalline rock showed that the unsaturated zone is generally several hundred meters below the bedrock surface (Maréchal, 1998; Masset \& Loew, 2010). We determined the water table by a set of trial and error runs. To do so, we set up a specific outlet that we determined by focusing on possible evidence of perennial water offspring that were found on the forefield of the Pèlerins glacier where water streams exist and a lake sometimes forms in the morainic material (Fig. 1b). To simplify our model domain and calculations, we neglected subglacial outlets. The recharge area is the ground surface to which we applied a water flow constrained by the hydraulic head $h$ (Neuman conditions automatically turned into Dirichlet conditions). Trial and errors simulations were run in unfrozen conditions with water input in meter per day (Neuman conditions) until a 
realistic and steady water table allowing further water infiltrations and preventing from either water outburst or substantial drainage was found. This initial water table was about $1000 \mathrm{~m}$ below the highest point of the topographical profile (Fig. 2). The resulting hydraulic head ranged between 2260 (elevation of the outlet) and $3826 \mathrm{~m}$ a.s.1.

The case $u S-L F$ relates to unsaturated conditions determined as describe here above and with very little water flow because the low hydraulic conductivity, even at saturation and the low porosity do not allow large flow into the rock matrix. The hydraulic head corresponding to the steady water table was applied as boundary condition (Dirichlet condition) replacing the Neuman condition used for trial and error simulations described above. These boundary conditions varied within a limited hydraulic head range (see sect. 2.3.4) in order to maintain unsaturated conditions during freezing and thawing phases, and conversely to $S a-F l$, this resulted in very little fluid flows because only a very low recharge was necessary.

Finally, a fourth case named $u S-F l$, aimed at testing the effect of enhanced water flow (discharge and recharge) into bedrock fractures. Because of some numerical limits (see discussion) and the aim of results transparency, water flow was enhanced into specific fractures and their vicinity, and at different periods (either during freezing or during thawing, see sect. 2.3.4). To do so, the hydraulic head varied during transient simulations at the top of the concerned fractures. This variable water flow forcing aimed at better see what happens into progressively suturing bedrock medium to refine characterization of water flow patterns and effects.

\begin{tabular}{|c|c|c|c|c|}
\hline & $S a-N F$ & Sa-Fl & $u S-L F$ & $u S \_F l$ \\
\hline $\boldsymbol{h}$ & $3830 \mathrm{~m}$ a.s.l. & Elevation of the surface & \multicolumn{2}{|c|}{2260 to $3826 \mathrm{~m}$ a.s.l. } \\
\hline outlet & None & $\begin{array}{l}\text { Created ad hoc by the } \\
\text { simulation process } \\
\text { (handled by the software) }\end{array}$ & \multicolumn{2}{|c|}{ Designed at the snout of the Pèlerins glacier } \\
\hline $\begin{array}{l}\text { Water } \\
\text { flow }\end{array}$ & None & $\begin{array}{l}\text { Constrained by steady } \\
\text { hydraulic head } \\
\text { provoking hydraulic } \\
\text { gradient }\end{array}$ & $\begin{array}{c} \pm 0.25 \% \text { of the } \\
\text { initial hydraulic } \\
\text { head }\end{array}$ & $\begin{array}{l} \pm 0.25 \% \text { of the initial } \\
\text { hydraulic head and } \\
\text { additional water input } \\
(+0.7 \mathrm{~m}) \text { until saturation is } \\
\text { reached at selected } \\
\text { fractures during freezing } \\
\text { and thawing }\end{array}$ \\
\hline
\end{tabular}

Table 1. Hydrological settings and forcing for the four study cases.

\subsubsection{Initialization and transient simulations}

\subsubsection{Initialization}

The models were first run for 3000 years until the water table ( $u S-L F$ and $u S$ - $F l$ cases only) and the bedrock temperature reached a steady state. A value of $+7^{\circ} \mathrm{C}$ was applied to the MARST of the 1961-1990 period to generate a non-frozen steady state. For $S a-F l$, the water input is controlled by the Dirichlet boundary conditions while for $u S-L F$ the Neuman boundary conditions are adjusted such as a steady unsaturated zone is maintained through time. 


\subsubsection{Transient simulations and forcing data}

Transient simulations are run at an automatically adapted and variable time step and cover a freezing period and a thawing period. They were run from $0 \mathrm{AD}$ (results of the initialization run) to $2100 \mathrm{AD}$. Using calendar dates was not necessary for our experiment as we do not intend to discuss past or future permafrost evolution patterns but we used them as the temperature time series was already created in a previous study (Magnin et al., 2017), that it represent realistic climate evolution, and that the dates facilitate results description.

In a first step, the entire bedrock is steadily frozen from $50 \mathrm{AD}$ to $1550 \mathrm{AD}$ (beginning of the Little Ice Age). To do so, a progressive temperature decrease of $8^{\circ} \mathrm{C}$ is applied at the surface, such as the MARST in $1550 \mathrm{AD}$ was $1^{\circ} \mathrm{C}$ lower than the MARST of the 1961-1990 period. In a second step, the freezing is kept constant (constant MARST) until the end of the Little Ice Age (1850). Within these two first steps, the initial hydraulic head is steadily reduced by $-0.25 \%$ (Dirichlet condition) for $u S-L F$ and $u S-F l$ as soon as the bedrock freezes, considering that no flow enters into the frozen rock and to prevent saturation when ice seals fractures. As the freezing is not uniform because of variable MARST, the decrease in $h$ is not uniform either. For $u S$ - $F l$, water is added (Neumann condition) in the only fracture reaching the water table during freezing, until saturation is reached. The freezing begins in $850 \mathrm{AD}$ in this fracture and the head starts to increase in $852 \mathrm{AD}$ at the top of the fracture until saturation $(+0.7 \mathrm{~m})$ in order to simulate infiltration. After this steady freezing, a progressive thawing starts by 1850 AD. The MARST first increases linearly by $+1^{\circ} \mathrm{C}$ until $1990 \mathrm{AD}$ (to match the MARST of the period 1961-1990) and then varies from a time step to another following the air temperature anomaly registered by Météo France in Chamonix and compared to the mean air temperature of 1961-1990. This approach strictly follows the one from Magnin et al. (2017) which has been shown reliable to reconstruct realistic permafrost evolution. Simulation are run until $2100 \mathrm{AD}$ and temperature anomaly is then calculated according to the IPSL_LR model of the CMIP5 project from 2015, assuming a greenhouse gas emission scenario of $+4.5 \mathrm{~W} . \mathrm{m}^{2}$ by the end of the $21^{\text {st }}$ century (RCP4.5, see Fig. 4 in Magnin et al. (2017)) for summary of the air temperature anomaly). Within the thawing period which lasts from 1850 to $2100 \mathrm{AD}$, the hydraulic head increases by $0.25 \%$ for $u S-L F$ and $u S-F l$ as soon as the bedrock starts to thaw. For $u S-F l$, water input $(+0.8 \mathrm{~m})$ is added in two other interconnected fractures until saturation is reached.

\section{Results}

\subsection{Temperature fields}

Figure 3 shows the temperature fields evolution after initialization ( 0 AD), freezing (1550 $\mathrm{AD})$ and thawing (1850 AD) for the $S a-N F, S a-F l$ and $u S-L F$ and Figure 4 focuses on specific timing and space scales of cases with enhanced fluid flows $(u S-F l$ and $S a-F l)$ to better show the water flow effect when thawing and freezing under variable saturation level.

Comparison of $S a-N F$ with $u S-L F$ (Fig. 3) shows that minor water flows have no effect on temperature fields distribution whatever the saturation level. Without sufficient fluid flows resulting of sufficient hydraulic gradient or saturation, heat transfer is purely conductive (Ingebritsen and Sanford, 1998). With a bedrock porosity of 5\%, the thermal conductivity and the heat capacity of the rock are the most influent parameters. Thus, temperature distribution mainly 
results of the topoclimatic control on surface temperature (air temperature lapse-rate and sunexposure) such as described in previous studies (e.g. Noetzli et al., 2007).

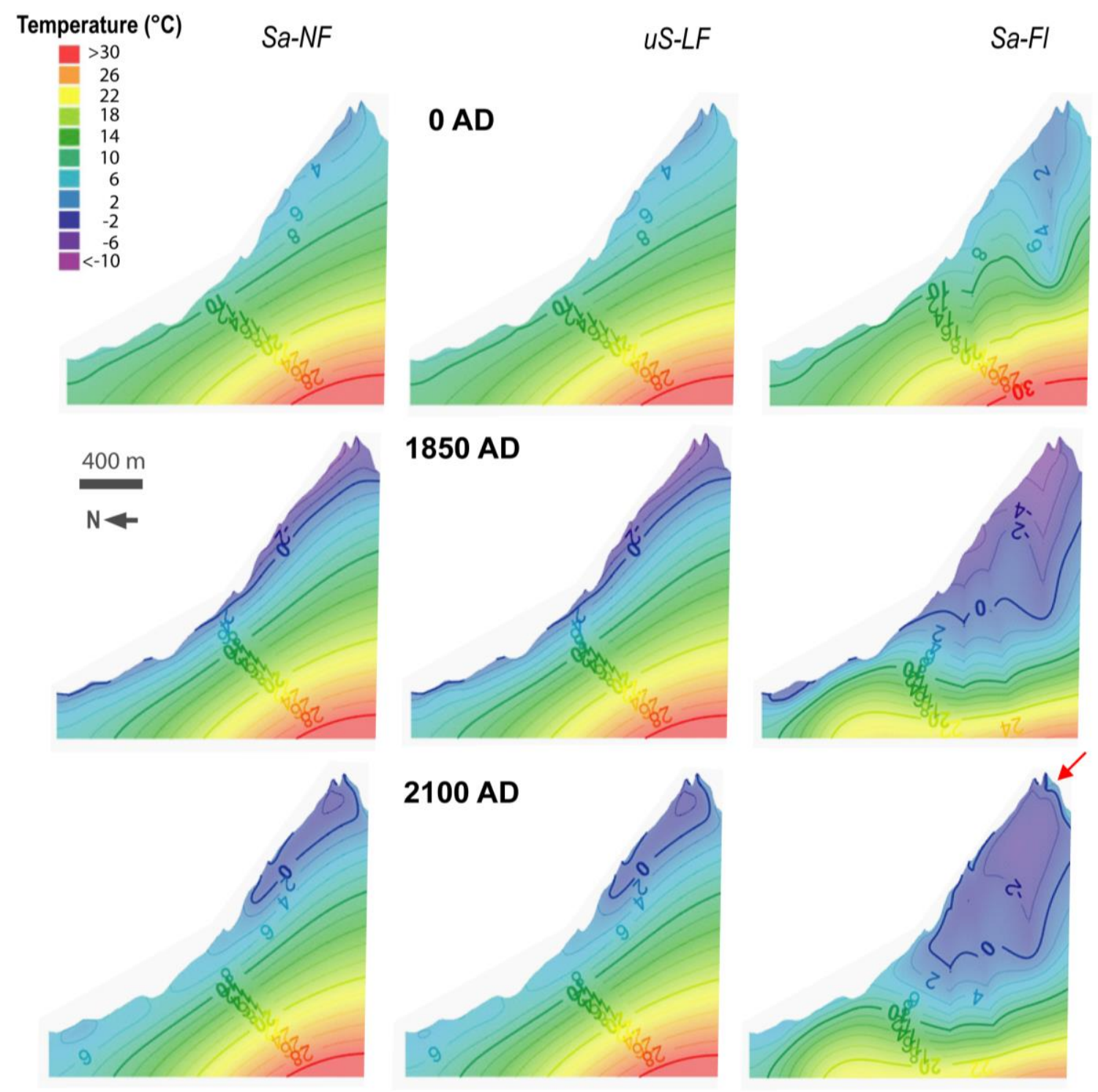

Figure 3. Temperature fields distribution in the mountain flank for steady and transient states when freezing and thawing. Red arrows point out area of intrest reported in Figure 4b.

Conversely, water flows provoked by the combination of high hydraulic gradients and saturated conditions have major effects on bedrock temperature. For $\mathrm{Sa}-\mathrm{Fl}$, temperature fields are affected in the whole domain and isotherm distortion is visible at the three timings (0, 1850 and 2100 AD) along the main fractures (Fig. 3). This corresponds to water flow pathways (see Fig. S2 for Darcy fluxes: they are several order of magnitude greater in the fractures than in the rock matrix) which drives the cold water from high-elevated areas to lower and warmer areas throughout these main flow paths (Ingebritsen and Sanford, 1998; Gallino et al., 2009; Thiébaud et al. 2010; Dzikowski et al., 2016). Cold corridors thus develop along the major fractures and gradually affects the 
surrounding rock matrix. These water flows stretch the permafrost body deeper than under no-flow or very low flow conditions such as for $u S-L F$. But saturation is a key parameter as exemplified by the $u S$ - $F l$ case (Fig. 4a): the freezing only starts in $850 \mathrm{AD}$ at this low-elevated fracture and the steady increase of the hydraulic head provoked at this time until saturation is followed by a temperature drop along the fracture down to more than $100 \mathrm{~m}$ depth. In the meantime, the saturation propagates in the rock matrix from the fracture, which extends the cold area around the fracture.

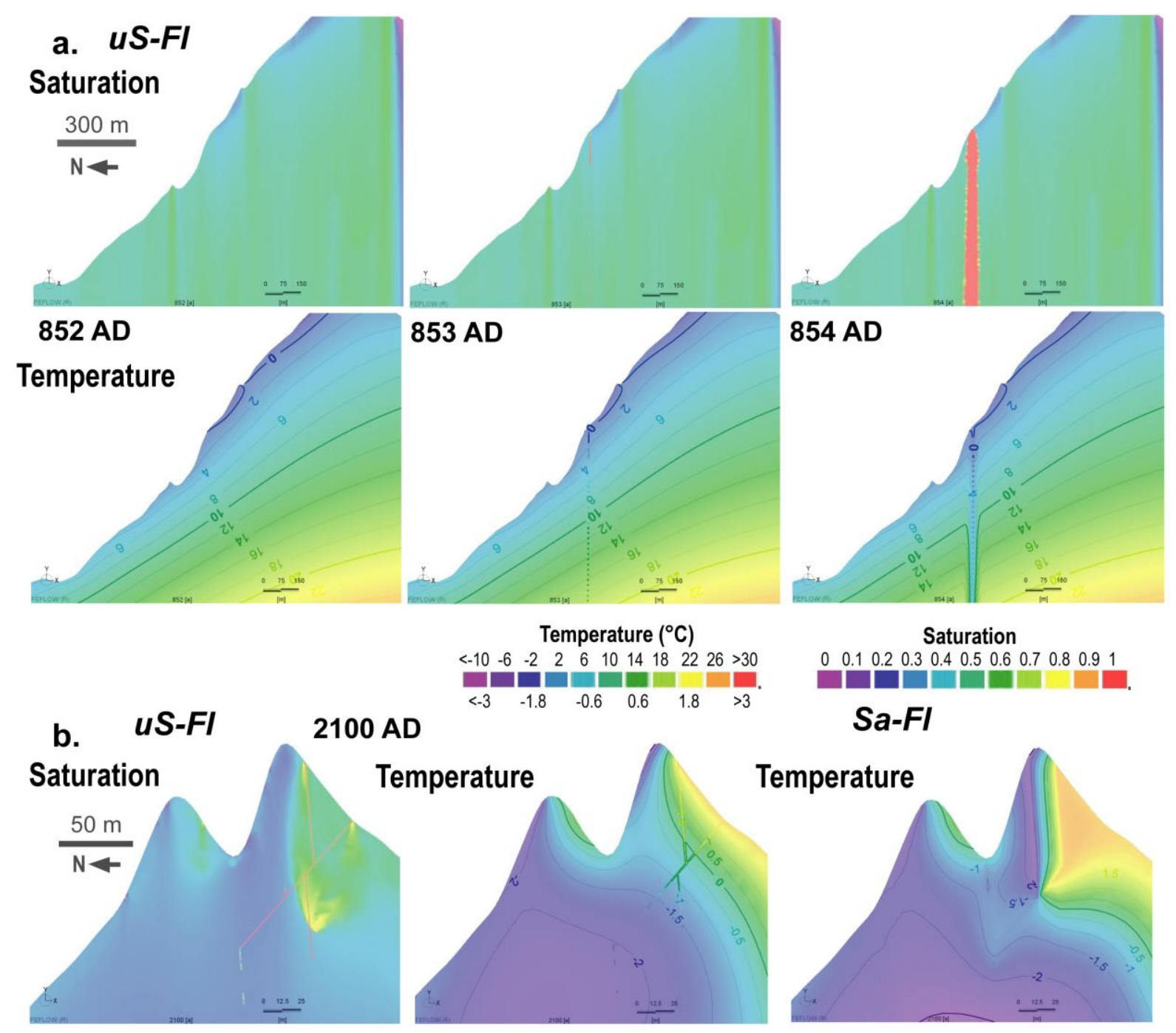

Figure 4. Thawing and freezing patterns under various saturation levels. a. Progressive fracture saturation and cooling under freezing conditions for the $u S-F l$ case. b. Relation between saturation and thawing patterns (saturation for $S a-F l$ is not displayed as it is fully saturated everywhere).

In the same way, thawing is also highly constrained by the saturation level but also by the temperature and fracture connectivity. When saturated or frozen up to the surface, thawing occurs through heat conduction only and the bedrock thaws before ice-filled fractures due to enhanced latent heat effects in the latter. This explains that permafrost warming and thawing between 1850 
and $2100 \mathrm{AD}$ is less along the deepest fractures for the case $\mathrm{Sa}-\mathrm{Fl}$ (Fig. 3). However, when the ice content starts to melt in the fracture, and is further enhanced by water infiltration, water flow starts and accelerates permafrost degradation (see red arrow on Fig. 3 for case $S a-F l$ and Fig. $4 \mathrm{~b}$ ). At the end of the thawing period (2100 AD), the isotherm $0^{\circ} \mathrm{C}$ has a square shape on the south-exposed face of the Central Pillar, that is constrained by the thawing fractures geometries. Figure $4 \mathrm{~b}$ shows that interconnected thawing fractures provoke much faster thawing in the rock matrix also than through heat conduction from the surface only. In this way, thawing is bottom-up (see Figure S3 for a more detailed chronicle). If the surrounding rock matrix is not saturated such as in the case of $u S-F l$, thawing corridors develop in the saturated fractures only. Under saturated conditions ( $S a$ $F l$ ), temperature gradients are exacerbated due to still frozen fractures on the north-exposed face and enhanced thawing around interconnected thawed fractures.

\subsection{Hydraulic behavior}

Figure 5 shows the hydraulic heads after initialization (0 AD), freezing (1550 AD) and thawing (1850 AD) for the $S a-N F, S a-F l$ and $u S-L F$. While temperature fields are the same for $S a$ $N F$ and $u S-L F$ at every time step displayed in Figure 3, hydraulic head are fairly different between the 2 cases and are merely the result of the chosen model parameterization to reduce water flow as much as possible. However, conversely to temperature fields, they remain identical through time for these 2 cases because water flows are not sufficient to provoke any perceptible head distortions. Minor perturbations appear during freezing or thawing but they are not visible at the given scale. For $u S-L F$, the hydraulic head roughly follows the elevation (with a 4-5 m negative offset related to the unsaturation) and equipotential lines are thus horizontal. However, for $\mathrm{Sa}-\mathrm{Fl}$ the equipotential lines have a vertical to subvertical pattern that is related to the direction of the main water flows along major vertical fractures and laterally from the fractures to the rock matrix.

Conversely to the 2 cases with no or little water flows, hydraulic heads are significantly affected by freezing and thawing for $\mathrm{Sa}-\mathrm{Fl}$. Fractures freeze top-down and steadily form frozen barriers that reduce water flows towards the rock matrix and thus lowers the hydraulic heads in the freezing rock portions. Because a fraction of liquid water is maintained in ice, and because of the permanent saturated conditions, water flows still occur in the main fractures, maintaining significant hydraulic head values which equipotential lines are shaped by fracture geometry. When only the fracture is saturated, head distortion is, similarly to temperature, only visible along the fracture (Fig. 6a). 

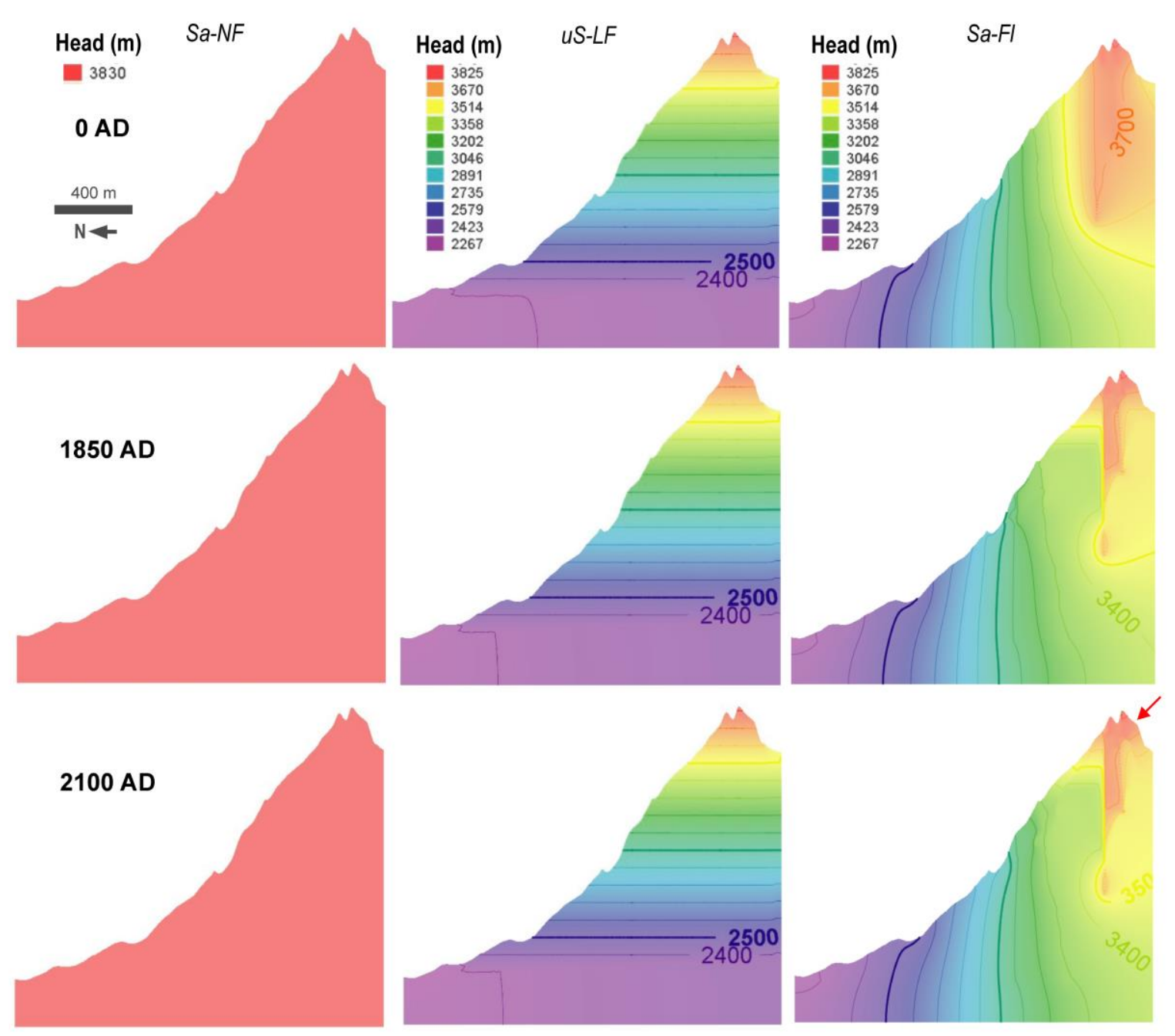

447 Figure 5. Hydraulic heads distribution in the mountain flank for steady and transient states when freezing and thawing. Red arrows point out area of intrest reported in Figure $6 b$.

When thawing occurs, the head increases again in thawing areas (red arrow on Fig. 5 and Fig. 6b). The equipotential lines shape moves from subhorizontal to subvertical as water flows are driven laterally from ice-blocked fractures to the thawed rock mass (see S3 for a more detailed chronicle). This observation reveals the behavior of a perched aquifer over an impermeable permafrost body. This lead to well higher hydraulic head values than in unsaturated or partially (fractures only) saturated conditions (Fig. 6b). Under unsaturated conditions, hydraulic head distortions are insignificant and become clearly perceptible along the fracture only and its surroundings when saturation of those occurs.

Therefore, the hydraulic behavior of rockwall permafrost follows similar principles as its thermal behavior: it is largely controlled by water flows in saturated areas. These local (fractures only) to more generalized head increase (propagation in the rock matrix) have strong implications for pressure distribution (see 5.2). 


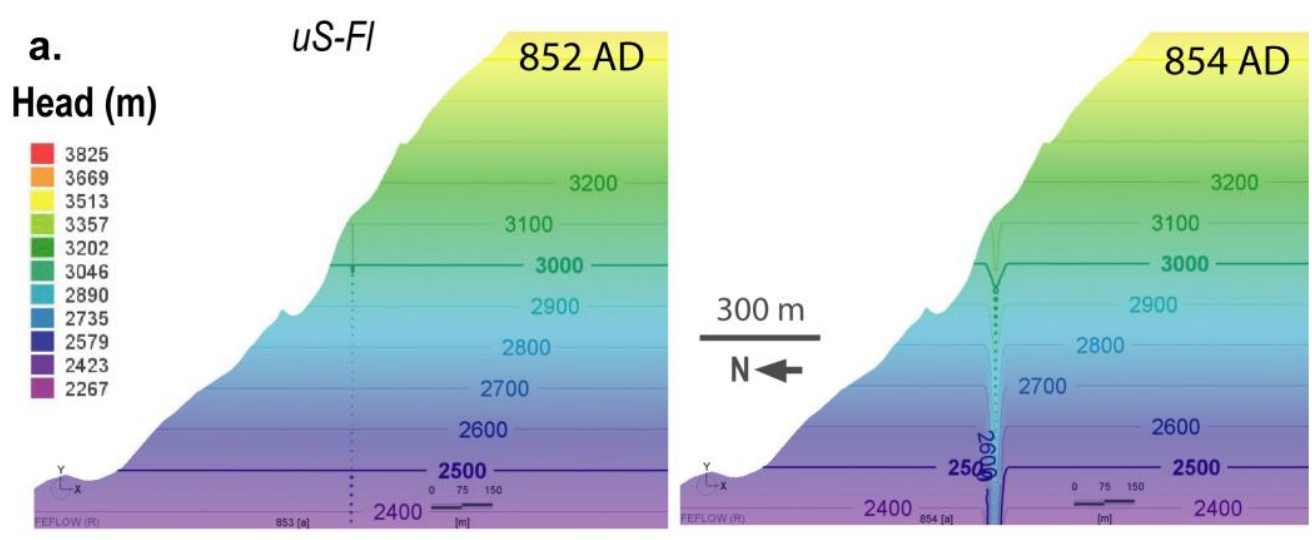

b.

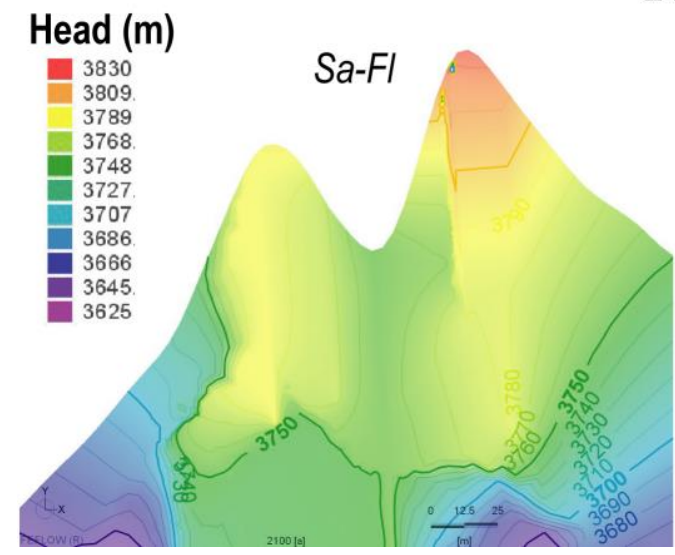

$2100 A D$

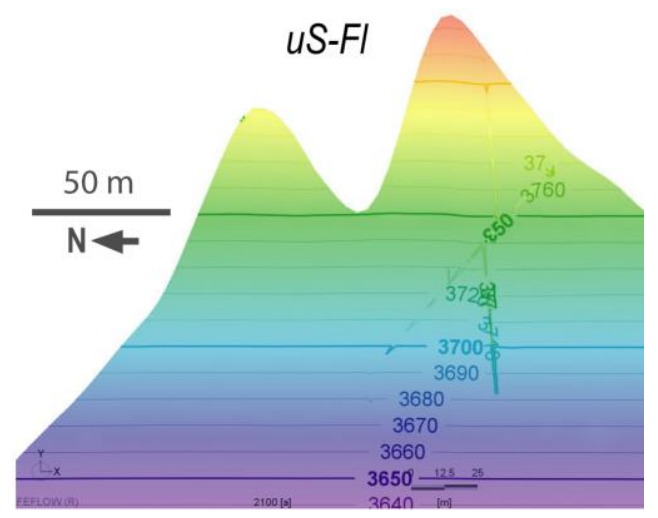

Figure 6. Hydraulic head patterns under various saturation levels. a. Progressive head increasing with saturation of the rock fracture and the rock mass when freezing (corresponding temperature and saturation are given in Fig. 4). b. Relation between saturation and hydraulic head patterns when thawing.

\section{Discussion}

5.1 Limits and future developments

Our study bears some conceptual and numerical limits which point out future research developments. Numerically, the large model domain discretized by a high amount of elements and nodes results in high CPU-time consumption, especially in unsaturated conditions (> 1 month for some simulations). This domain size was chosen because we adopted a hydrogeological approach for which considering an entire mountain flank was necessary. However, the use of such hydrothermal model for geomorphological purposes (understanding bedrock failure for example) could be based on a reduced model domain. In addition, repeated numerical instabilities occurred when running simulations for unsaturated conditions. This is 
most likely due to the non-linearity of the equations of the unsaturated flow that are usually not used for so high unsaturated zones as well as in freezing and thawing bedrock.

Such numerical limitations could challenge the consideration of shorter-term freeze and thaw cycles such as the seasonal ones which are relevant for geomorphological concerns. A reduction of the model domain should be considered for such purposes. This would involve to setup a perched water table. The scientific literature mentioning water table level in crystalline massif like in our study is really poor. Most knowledge comes from random measurements and assumptions. The study from Masset \& Loew (2010) reports a height of up to $400 \mathrm{~m}$ of unsaturated zone in a crystalline massif of the European Alps. But its value cannot be generalized and should be apprehended in light of local topographical settings. The Aiguille du Midi, that is the western margin of the Aiguilles de Chamonix, is located in a unique topographical context characterized by $>1000 \mathrm{~m}$ high granitic rockwalls overhanging the valley shoulder. Permanent streams reflecting a natural water table are only found on this shoulder, and our water table settings does not seem irrelevant. However, the absence of permanent streams in the rockwalls may rather reflect a permafrost-related aquiclude than unsaturated rockwalls. During the past hot summers such as 2015 or 2019, numerous springs intermittently appeared in the rockwalls of the Mont Blanc massif and are assumed to be linked to temporary drainage of bedrock fractures above perched acquiclude. Observation and investigation of these temporary offsprings should help in conceptualizing perched water tables in rockwall permafrost that our simplified model represented on the thawing sunny faces (red arrows in Fig. 3 and 5, Fig. 4 and 6). These observations do not allow to understand the detailed functioning of perched acquiclude but at least showed that our modeling approach allows to simulate them which might then be relevant to understand rockwall permafrost mechanics (Fischer et al., 2010; Stoll et al., 2020). The water table defined in the frame of our study, was however relevant to address long-term hydraulic and thermal behavior of high-mountain rockwalls with implications for questioning hydrothermal regime in alpine environments.

In the same way, water inputs were determined according to our research objectives which were to investigate the effect of saturated versus unsaturated conditions. We thus adapted the hydraulic head in order to represent those different saturation conditions, but not to account for realistic water input. Realistic water input could be considered in future developments to address the role of snow melt infiltration or rain events on the permafrost dynamics (see 5.2).

Another limit is related to the chosen fracture set that was composed of few but widely open fractures overlooking the role of fracture density. We thus had to ensure bedrock permeability by accounting for a rather high porosity indirectly representing fracture density and weathered zones such as in former thermal modeling approach (Magnin et al., 2017; Noetzli et al., 2007). At a reduced spatial scale, it would be relevant to implement a more realistic rock matrix (less porous) combined with more realistic set of fractures (a dense network of thin fractures in addition to the most important ones) as granitic bedrock permeability is mostly dependent on the fracture network characteristics (Hsieh, 1998; Renshaw, 1996; 1997).

It is also noteworthy to point out that Feflow simulates saturation from top to bottom in the fractures, which is not necessarily the case in natural environments. Improvements in the modeling approach in order to setup more realistic hydrological processes representing water 
percolation along the fracture and its accumulation at the ice cement as described by Hasler et al. (2011a) should be considered for more detailed investigations.

Finally, other improvements could be performed by considering air convection in unsaturated fractures which likely cools the bedrock (Hasler et al., 2011b), a 3D geometry which would better account for high hydraulic and thermal gradients, but would also challenge the calculation capacity, or turbulent heat fluxes that may locally affect cleft ice erosion and heat transfers (Hasler et al., 2011a).

\subsection{Results implications}

The results of this study bear strong implications for understanding permafrost dynamics and its response to climate change, alpine morphodynamics, alpine hydrogeology and hazards assessment.

Permafrost temperature and active layer thickness are recognized as Essential Climate Variables by the Global Climate Observing System. Understanding their response to climate change is thus of global concern to apprehend the environmental impact of atmospheric warming. Simulations run with water flows show that rockwall permafrost dynamics are more complex than previously thought. Water stretches the permafrost body deeper than under purely conductive transfer, meaning that it may be present in areas not predictd by thrmal models accounting for heat conduction only. Because of ice bodies occupying large fractures, thawing may be either delayed or enhanced, while in the nearby rock mass, thawing corridors and area may develop in and from fractures. Interconnected fractures may enhance thawing at depth, in areas delineated by those fractures and promote bottom-up permafrost degradation. Thawing corridors along fractures were already suggested by experimental or geophysical investigations (Hasler et al., 2011a; Keuschnig et al., 2017; Krautblatter \& Hauck, 2007), and the numerical approach proposed in this study could be essential to conduct systematic investigations on such processes in order to quantitatively scale the effects of fracture aperture, dipping, density, connectivity and temperature, as well as the effects of water inflow characteristics (amount, temperature, timing of infiltration) on permafrost dynamics. In addition, coupled thermal and hydrological models could help investigating the effect of snow or glaciers melting water and rainfalls infiltrations in the rock mass, some processes that have been so far overlooked in theconceptualization of rockwall permafrost evolution.

Besides understanding thermal dynamics, our results may provide relevant knowledge to understand cold water anomalies found during deep geotechnical work such as tunneling (Maréchal et al., 1999; Maréchal, 1998; Mommessin, 2015). Such anomalies are attributed to cold water infiltrating from mountain top which are in some cases glaciated and our findings further question the role of permafrost in alpine hydrothermal processes.

Thawing corridors and strongly variable hydraulic heads further bear implication for understanding rock failure hazards in periglacial environments. The warming or thawing of icefilled fractures altering their shear resistance or provoking a loss of rock-ice contact are currently recognized as the main permafrost-related triggering factors of rockfalls (Davies et al., 2001; Krautblatter et al., 2013; Mamot et al., 2018; Matsuoka \& Murton, 2008). But high hydrostatic pressures related to perched acquifer is also thought to play a role in rockwall destabilization 
(Fischer et al., 2010; Walter et al., 2020). However, those fluid pressures are the less understood and recent developments in mechanical modeling have shown that hydrostatic pressure of 0.1 MPa over an impermeable permafrost body could trigger rock slope failure (Stoll et al., 2020). Our results show that such critical level of hydrostatic pressure may be reached with hundreds of $\mathrm{kPa}$ associated to thawed bedrock, either locally in water saturated fractures or in the entire thawed rock matrix (Fig. 7), hinting at favorable conditions for rockwall destabilization.

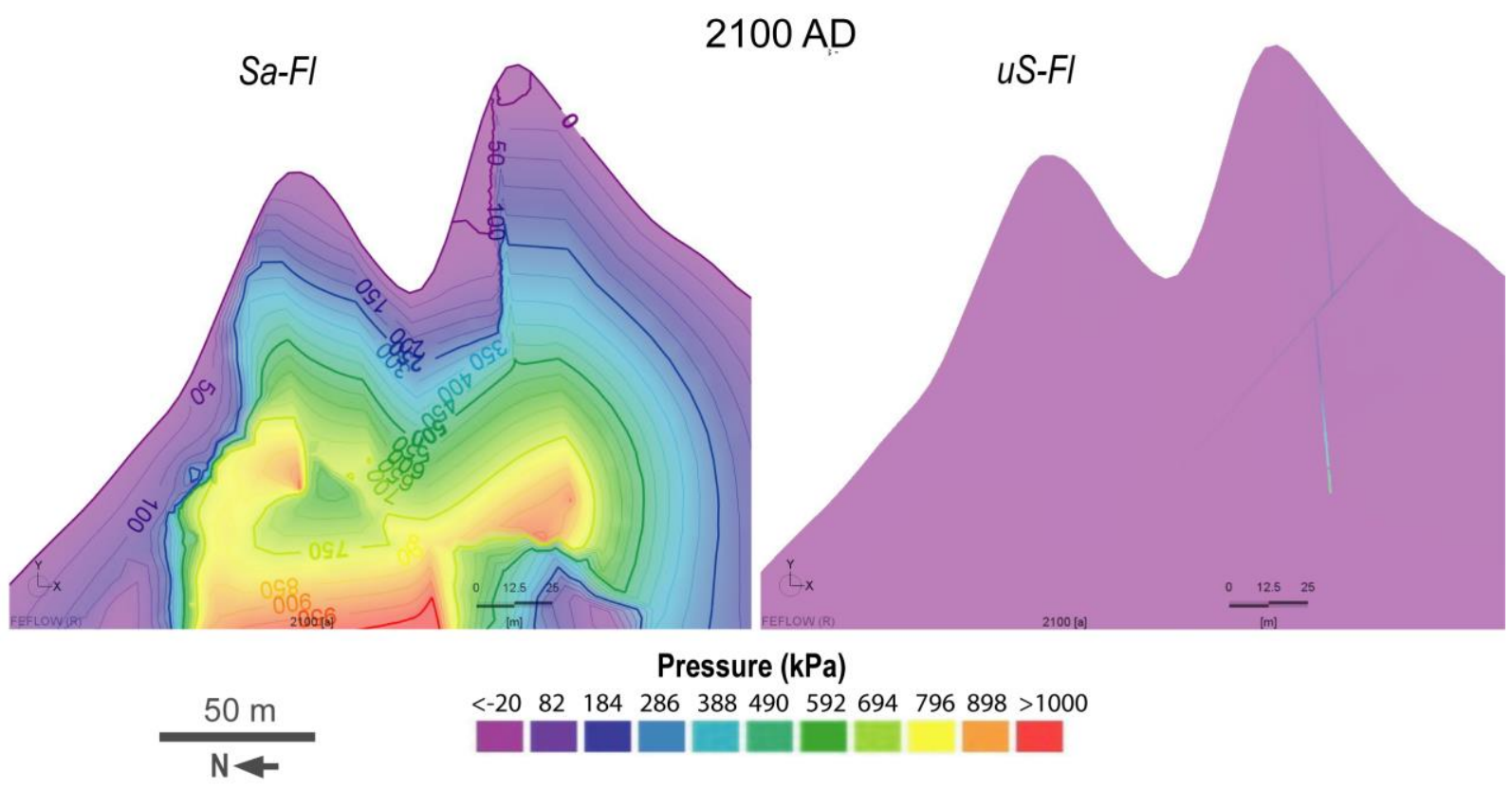

Figure 7. Pressure fields in 2100 AD for different saturation levels.

Finally, as already concluded by Hasler et al. (2011a), our study confirms that thawing corridors but also thawing areas delineated by thawing fractures may explain rockfall triggering in cold permafrost areas or before the maximum active layer depth (Gruber et al., 2004; Luethi et al., 2015). It also shows that frozen fractures may be found in thawed bedrock.

\section{Conclusions and outlooks}

In this study, we propose the very first fully coupled hydrological and thermal models applied to rockwall permafrost. As a preliminary approach, we adopted a hydrogeological conceptualization and considered a mountain flank as model domain. Our model set up resulted in very high CPU-time but this study could serve as a baseline for future modeling developments focusing on a reduced model domain. We run four simulations accounting for variable saturation levels and water flows. We draw the following conclusions:

- Water flows have major effects on the aggradation and degradation of alpine rockwall permafrost. They drive the cold from top to bottom when permafrost forms resulting in a deeper permafrost body than under heat conduction only. Ice-cement in bedrock fractures 
first delays permafrost degradation compared to surrounding bedrock but then accelerates it as soon as ice starts to melt.

- Thawing fractures act as thawing corridors accelerating permafrost degradation at depth. When surrounding bedrock is saturated, interconnected thawing fractures create thawing wedges provoking bottom-up permafrost degradation.

- Fractures exacerbate thermal gradients due to enhanced frost in still ice-cemented fractures that can be in the vicinity of thawing corridors or wedges (exacerbation of the north-south contrasts for example). In this respect, frozen fractures may subsist in thawed bedrock and thawed areas may form in frozen bedrock.

- Bedrock permeability is dependent on fracturing as water flows mostly occur along fractures and remain minimal in the bedrock matrix, notably in unsaturated conditions. In saturated conditions, water first flows in the fracture and then towards the bedrock matrix.

- Water flows provoke very unequal hydraulic head distribution and related fluid pressures. In a saturated and fractured medium, equipotential lines follow fracture shapes.

- Thawing results in high hydraulic head and fluid pressure than can reach several hundreds of $\mathrm{kPa}$ over or within the permeable permafrost body.

- Thermal and hydraulic patterns of rockwall permafrost are strongly affected by fluid flows under saturated conditions only. Unsaturated conditions substantially minor their effect. Knowing the level of saturation of bedrock fractures is thus highly relevant to understand permafrost evolution and rockwall destabilization patterns.

This study bears strong implications for understanding permafrost response to climate change, rock slope failure, related hazards and geomorphic processes, as well as alpine hydrogeology. Future developments would benefit of a reduced model domain accounting for a perched water table, realistic fracture sets and water inflows to bettr characterize water flow effects.

\section{Acknowledgments and Data availability}

This study is funded by the ANR-19-CE01-0018 WISPER project. Model input, forcing and output data are available on the Zenodo data repository: https://doi.org/10.5281/zenodo.3958847

\section{References}

Allen, S. K., Gruber, S., \& Owens, I. F. (2009). Exploring steep bedrock permafrost and its relationship with recent slope failures in the Southern Alps of New Zealand. Permafrost and Periglacial Processes, 20(4), 345-356. https://doi.org/10.1002/ppp.658

Bense, V. F., Kooi, H., Ferguson, G., \& Read, T. (2012). Permafrost degradation as a control on hydrogeological regime shifts in a warming climate. Journal of Geophysical Research: Earth Surface, 117(F3). https://doi.org/10.1029/2011JF002143 
Boeckli, L., Brenning, A., Gruber, S., \& Noetzli, J. (2012). A statistical approach to modelling permafrost distribution in the European Alps or similar mountain ranges. The Cryosphere, 6(1), 125-140. https://doi.org/10.5194/tc-6-125-2012

Burt, T. P., \& Williams, P. J. (1976). Hydraulic conductivity in frozen soils. Earth Surface Processes, 1(4), 349-360. https://doi.org/10.1002/esp.3290010404

Clausnitzer, V. and Mirnyy, V. (2015). Freeze/Thaw plug-in for FEFLOW, Feflow reference manual, 6 pp.

Cochand, M., Christe, P., Ornstein, P., \& Hunkeler, D. (2019). Groundwater Storage in High Alpine Catchments and Its Contribution to Streamflow. Water Resources Research, 55(4), 26132630. https://doi.org/10.1029/2018WR022989

Davies, M. C. R., Hamza, O., \& Harris, C. (2001). The effect of rise in mean annual temperature on the stability of rock slopes containing ice-filled discontinuities. Permafrost and Periglacial Processes, 12(1), 137-144. https://doi.org/10.1002/ppp.378

Deline, P., Broccolato, M., Noetzli, J., Ravanel, L., \& Tamburini, A. (2013). The December 2008 Crammont Rock Avalanche, Mont Blanc Massif Area, Italy. In C. Margottini, P. Canuti, \& K. Sassa (Eds.), Landslide Science and Practice: Volume 4: Global Environmental Change (pp. 403-408). Berlin, Heidelberg: Springer. https://doi.org/10.1007/978-3-642-31337-0_52

\section{Diersch H.-J. G. (2004). WASY FEFLOW, White Papers Vol. I, Chapter 9 Discrete feature} modeling of flow, mass and heat transport processes by using Feflow, p. 149-196.

Dzikowski M. Josnin J.-Y. and Roche N. (2016). Thermal Influence of an Alpine Deep Hydrothermal Fault on the Surrounding Rocks-Groundwater Vol. 54, 55-65

Fischer, L., Amann, F., Moore, J. R., \& Huggel, C. (2010). Assessment of periglacial slope stability for the 1988 Tschierva rock avalanche (Piz Morteratsch, Switzerland). Engineering Geology, 116(1), 32-43. https://doi.org/10.1016/j.enggeo.2010.07.005

Frauenfelder, R., Isaksen, K., Lato, M. J., \& Noetzli, J. (2018). Ground thermal and geomechanical conditions in a permafrost-affected high-latitude rock avalanche site (Polvartinden, northern Norway). The Cryosphere, 12(4), 1531-1550. https://doi.org/10.5194/tc12-1531-2018

Gallino S., Josnin, J.-Y., Dzikowski, M., Cornaton F., and Gasquet, D. (2009), The influence of paleoclimatic events on the functioning of an alpine thermal system (France): the contribution of hydrodynamic-thermal modeling, Hydrogeology Journal, 17, p. 1887-1900.

Geertsema, M., Clague, J. J., Schwab, J. W., \& Evans, S. G. (2006). An overview of recent large catastrophic landslides in northern British Columbia, Canada. Engineering Geology, 83(1), 120143. https://doi.org/10.1016/j.enggeo.2005.06.028

Grenier, C., Anbergen, H., Bense, V. F., Chanzy, Q., Coon, E., Collier, N., et al. (2018). Groundwater flow and heat transport for systems undergoing freeze-thaw: Intercomparison of numerical simulators for 2D test cases. Advances in Water Resources, 114, 196-218. https://doi.org/10.1016/j.advwatres.2018.02.001

Gruber, S., \& Haeberli, W. (2007). Permafrost in steep bedrock slopes and its temperaturerelated destabilization following climate change. Journal of Geophysical Research: Earth Surface, 112(F2). https://doi.org/10.1029/2006JF000547 
Gruber, Stephan, Hoelzle, M., \& Haeberli, W. (2004). Permafrost thaw and destabilization of Alpine rock walls in the hot summer of 2003. Geophysical Research Letters, 31(13). https://doi.org/10.1029/2004GL020051

Hallet, B., Walder, J. S., \& Stubbs, C. W. (1991). Weathering by segregation ice growth in microcracks at sustained subzero temperatures: Verification from an experimental study using acoustic emissions - Hallet - 1991 - Permafrost and Periglacial Processes - Wiley Online Library. Retrieved October 31, 2019, from https://onlinelibrary.wiley.com/doi/abs/10.1002/ppp.3430020404

Hasler, Andreas, Gruber, S., Font, M., \& Dubois, A. (2011a). Advective Heat Transport in Frozen Rock Clefts: Conceptual Model, Laboratory Experiments and Numerical Simulation. Permafrost and Periglacial Processes, 22(4), 378-389. https://doi.org/10.1002/ppp.737

Hasler, A., Gruber, S., \& Haeberli, W. (2011b). Temperature variability and offset in steep alpine rock and ice faces. The Cryosphere, 5(4), 977-988. https://doi.org/10.5194/tc-5-977-2011

Hsieh, P. A. (1998). Scale Effects in Fluid Flow through Fractured Geologic Media. In G. Sposito (Ed.), Scale Dependence and Scale Invariance in Hydrology (pp. 335-353). Cambridge: Cambridge University Press. https://doi.org/10.1017/CBO9780511551864.013

Ingebritsen S.E. and Sanford W.E., 1998, Groundwater in Geologic processes, Cambridge University Press, $341 \mathrm{pp}$.

Keuschnig, M., Krautblatter, M., Hartmeyer, I., Fuss, C., \& Schrott, L. (2017). Automated Electrical Resistivity Tomography Testing for Early Warning in Unstable Permafrost Rock Walls Around Alpine Infrastructure. Permafrost and Periglacial Processes, 28(1), 158-171. https://doi.org/10.1002/ppp.1916

Krautblatter, M., \& Hauck, C. (2007). Electrical resistivity tomography monitoring of permafrost in solid rock walls. Journal of Geophysical Research: Earth Surface, 112(F2). https://doi.org/10.1029/2006JF000546

Krautblatter, M., Huggel, C., Deline, P., \& Hasler, A. (2012). Research Perspectives on Unstable High-alpine Bedrock Permafrost: Measurement, Modelling and Process Understanding. Permafrost and Periglacial Processes, 23(1), 80-88. https://doi.org/10.1002/ppp.740

Krautblatter, M., Funk, D., \& Günzel, F. K. (2013). Why permafrost rocks become unstable: a rock-ice-mechanical model in time and space. Earth Surface Processes and Landforms, 38(8), 876-887. https://doi.org/10.1002/esp.3374

Luethi, R., Gruber, S., \& Ravanel, L. (2015). Modelling transient ground surface temperatures of past rockfall events: towards a better understanding of failure mechanisms in changing periglacial environments. Geografiska Annaler: Series A, Physical Geography, 97(4), 753-767. https://doi.org/10.1111/geoa.12114

Luethi, R., Phillips, M., \& Lehning, M. (2017). Estimating Non-Conductive Heat Flow Leading to Intra-Permafrost Talik Formation at the Ritigraben Rock Glacier (Western Swiss Alps). Permafrost and Periglacial Processes, 28(1), 183-194. https://doi.org/10.1002/ppp.1911

Magnin, F., Brenning, A., Bodin, X., Deline, P., \& Ravanel, L. (2015). Statistical modelling of rock wall permafrost distribution: application to the Mont Blanc massif. Géomorphologie : Relief, Processus, Environnement, 20. 
Magnin, F., Josnin, J.-Y., Ravanel, L., Pergaud, J., Pohl, B., \& Deline, P. (2017). Modelling rock wall permafrost degradation in the Mont Blanc massif from the LIA to the end of the 21st century. The Cryosphere, 11(4), 1813-1834. https://doi.org/10.5194/tc-11-1813-2017

Mamot, P., Weber, S., Schröder, T., \& Krautblatter, M. (2018). A temperature- and stresscontrolled failure criterion for ice-filled permafrost rock joints. The Cryosphere, 12(10), 33333353. https://doi.org/10.5194/tc-12-3333-2018

Maréchal, J. C., Perrochet, P., \& Tacher, L. (1999). Long-term simulations of thermal and hydraulic characteristics in a mountain massif: The Mont Blanc case study, French and Italian Alps. Hydrogeology Journal, 7(4), 341-354. https://doi.org/10.1007/s100400050207

Maréchal, J. C., Dewandel, B., \& Subrahmanyam, K. (2004). Use of hydraulic tests at different scales to characterize fracture network properties in the weathered-fractured layer of a hard rock aquifer. Water Resources Research, 40(11). https://doi.org/10.1029/2004WR003137

Maréchal, J.-C. (1998). Les circulations d'eau dans les massifs cristallins alpins et leurs relations avec les ouvrages souterrains (phd thesis). Ecole Polytechnique Fédérale de Lausanne (EPFL), Lausanne, Switzerland, Retrieved from https://tel.archives-ouvertes.fr/tel-00454009

Masset, O., \& Loew, S. (2010). Hydraulic conductivity distribution in crystalline rocks, derived from inflows to tunnels and galleries in the Central Alps, Switzerland. Hydrogeology Journal, 18(4), 863-891. https://doi.org/10.1007/s10040-009-0569-1

Matsuoka, N. (2001). Microgelivation versus macrogelivation: towards bridging the gap between laboratory and field frost weathering. Permafrost and Periglacial Processes, 12(3), 299-313. https://doi.org/10.1002/ppp.393

Matsuoka, N., \& Murton, J. (2008). Frost weathering: recent advances and future directions. Permafrost and Periglacial Processes, 19(2), 195-210. https://doi.org/10.1002/ppp.620

McKenzie, J. M., \& Voss, C. I. (2013). Permafrost thaw in a nested groundwater-flow system. Hydrogeology Journal, 21(1), 299-316. https://doi.org/10.1007/s10040-012-0942-3

Mommessin, G. (2015) Etude des perturbations thermiques profondes associées aux contextes hydrogéologiques et paléo-environnementaux des massifs alpins, exemple du versant sud de la moyenne Maurienne, PhD thesis, University Grenoble Alpes, Chambéry, France 225 pp. NNT: 2015GREAA013, tel-01272533

Noetzli, J., \& Gruber, S. (2009). Transient thermal effects in Alpine permafrost. The Cryosphere, 3(1), 85-99. https://doi.org/10.5194/tc-3-85-2009

Noetzli, Jeannette, Gruber, S., Kohl, T., Salzmann, N., \& Haeberli, W. (2007). Threedimensional distribution and evolution of permafrost temperatures in idealized high-mountain topography. Journal of Geophysical Research: Earth Surface, 112(F2). https://doi.org/10.1029/2006JF000545

Phillips, M., Haberkorn, A., Draebing, D., Krautblatter, M., Rhyner, H., \& Kenner, R. (2016). Seasonally intermittent water flow through deep fractures in an Alpine Rock Ridge: Gemsstock, Central Swiss Alps. Cold Regions Science and Technology, 125, 117-127. https://doi.org/10.1016/j.coldregions.2016.02.010

Renshaw C.E. 1996, Estimation of fracture zone geometry from steady-state hydraulic head datausing iterative sequential cokriging, Geophysical Research Letters, 23(9), 2685-2688. 
Renshaw C.E. 1997, Mechanical control on the spatial density of opening-mode fracture networks, Geology, 25(10), 923-926.

Ravanel, L., Magnin, F., \& Deline, P. (2017). Impacts of the 2003 and 2015 summer heatwaves on permafrost-affected rock-walls in the Mont Blanc massif. Science of The Total Environment, 609, 132-143. https://doi.org/10.1016/j.scitotenv.2017.07.055

Rowland, J. C., Travis, B. J., \& Wilson, C. J. (2011). The role of advective heat transport in talik development beneath lakes and ponds in discontinuous permafrost. Geophysical Research Letters, 38(17). https://doi.org/10.1029/2011GL048497

Scherler, M., Hauck, C., Hoelzle, M., Stähli, M., \& Völksch, I. (2010). Meltwater infiltration into the frozen active layer at an alpine permafrost site. Permafrost and Periglacial Processes, 21(4), 325-334. https://doi.org/10.1002/ppp.694

Snow, D.T. (1979). Anisotropic permeability of fractured media. Water Resources Research, 5: $1273-1279$.

Staudinger, M., Stoelzle, M., Seeger, S., Seibert, J., Weiler, M., \& Stahl, K. (2017). Catchment water storage variation with elevation. Hydrological Processes, 31(11), 2000-2015. https://doi.org/10.1002/hyp.11158

Stoll, V., Scandroglio, R., \& Krautblatter, M. (2020). Modlling rock walls destabilization caused by hydrostatic pressure in frozen/unfrozen bedrock (Hochvogel \& Zugspitze, Germany) (Vol. 14338). Presented at the EGU General Assembly, Vienna, Austria. https://doi.org/doi.org/10.5194/egusphere-egu2020-14338

Thiébaud, E., S. Gallino, M. Dzikowski, and G. Gasquet. 2010. The influence of glaciations on the dynamics of mountain hydrothermal systems: Numerical modeling of the La Léchère system (Savoie, France). Bulletin de la Sociéte Géologique de France 181, no. 4: 295-304.

Walder, J., \& Hallet, B. (1985). A theoretical model of the fracture of rock during freezing. GSA Bulletin, 96(3), 336-346. https://doi.org/10.1130/0016-7606(1985)96<336:ATMOTF>2.0.CO;2

Walter, F., Amann, F., Kos, A., Kenner, R., Phillips, M., de Preux, A., et al. (2020). Direct observations of a three million cubic meter rock-slope collapse with almost immediate initiation of ensuing debris flows. Geomorphology, 351, 106933.

https://doi.org/10.1016/j.geomorph.2019.106933

Zhao, J. (1998). Rock mass hydraulic conductivity of the Bukit Timah granite, Singapore. Engineering Geology, 50(1), 211-216. https://doi.org/10.1016/S0013-7952(98)00021-0 